\title{
Lipid accumulation in non-adipose tissue and lipotoxicity
}

Citation for published version (APA):

van Herpen, N. A., \& Schrauwen-Hinderling, V. B. (2008). Lipid accumulation in non-adipose tissue and lipotoxicity. Physiology \& Behavior, 94(2), 231-241. https://doi.org/10.1016/j.physbeh.2007.11.049

Document status and date:

Published: 01/01/2008

DOI:

10.1016/j.physbeh.2007.11.049

Document Version:

Publisher's PDF, also known as Version of record

Document license:

Taverne

Please check the document version of this publication:

- A submitted manuscript is the version of the article upon submission and before peer-review. There can be important differences between the submitted version and the official published version of record.

People interested in the research are advised to contact the author for the final version of the publication, or visit the DOI to the publisher's website.

- The final author version and the galley proof are versions of the publication after peer review.

- The final published version features the final layout of the paper including the volume, issue and page numbers.

Link to publication

\footnotetext{
General rights rights.

- You may freely distribute the URL identifying the publication in the public portal. please follow below link for the End User Agreement:

www.umlib.nl/taverne-license

Take down policy

If you believe that this document breaches copyright please contact us at:

repository@maastrichtuniversity.nl

providing details and we will investigate your claim.
}

Copyright and moral rights for the publications made accessible in the public portal are retained by the authors and/or other copyright owners and it is a condition of accessing publications that users recognise and abide by the legal requirements associated with these

- Users may download and print one copy of any publication from the public portal for the purpose of private study or research.

- You may not further distribute the material or use it for any profit-making activity or commercial gain

If the publication is distributed under the terms of Article $25 \mathrm{fa}$ of the Dutch Copyright Act, indicated by the "Taverne" license above, 


\title{
Lipid accumulation in non-adipose tissue and lipotoxicity
}

\author{
N.A. van Herpen ${ }^{a, b, *}$, V.B. Schrauwen-Hinderling ${ }^{b}$ \\ ${ }^{a}$ Top Institute Food and Nutrition, 6700 AN Wageningen, The Netherlands \\ ${ }^{\mathrm{b}}$ Department of Human Biology, Nutrition and Toxicology Research Institute of Maastricht, Maastricht University, 6200 MD Maastricht, The Netherlands
}

Received 1 August 2007; received in revised form 21 November 2007; accepted 22 November 2007

\begin{abstract}
Obesity is a well-known risk factor for the development of type 2 diabetes mellitus and cardiovascular disease. Importantly, obesity is not only associated with lipid accumulation in adipose tissue, but also in non-adipose tissues. The latter is also known as ectopic lipid accumulation and may be a possible link between obesity and its comorbidities such as insulin resistance, type 2 diabetes mellitus and cardiovascular disease.

In skeletal muscle and liver, lipid accumulation has been associated with the development of insulin resistance, an early hallmark of developing type 2 diabetes mellitus. More specifically, accumulation of intermediates of lipid metabolism, such as diacylglycerol (DAG) and Acyl-CoA have been shown to interfere with insulin signaling in these tissues. Initially, muscular and hepatic insulin resistance can be overcome by an increased insulin production by the pancreas, resulting in hyperinsulinemia. However, during the progression towards overt type 2 diabetes, pancreatic failure occurs resulting in reduced insulin production. Interestingly, also in the pancreas lipid accumulation has been shown to precede dysfunction.

Finally, accumulation of fat in the heart has been associated with cardiac dysfunction and heart failure, which may be an explanation for diabetic cardiomyopathy.

Taken together, we conclude that evidence for deleterious effects of lipid accumulation in non-adipose tissue (lipotoxicity) is strong. However, while ample human data is available for skeletal muscle and the liver, future research should focus on lipid accumulation in the pancreas and the heart.
\end{abstract}

(C) 2007 Elsevier Inc. All rights reserved.

Keywords: Lipid accumulation; Non-adipose tissue; Lipotoxicity; Ectopic fat

\section{Introduction}

Obesity is due to a chronic positive energy balance, which increases the amount of triglycerides (TG) in adipose tissue. However, the TG can also be stored in non-adipose tissue, such as muscle, liver, pancreas and heart. Indeed, obesity has been shown to lead to excessive deposition of TG in these organs, which is termed ectopic fat deposition or steatosis. Lipid droplets accumulate in the cytoplasm of the cells and an excessive accumulation of these lipids may lead to cell dysfunction or cell death, a phenomenon known as lipotoxicity $[1,2]$. Obese individuals are at much greater risk of developing

\footnotetext{
* Corresponding author. Department of Human Biology, University Maastricht, P.O. Box 616, 6200 MD Maastricht, The Netherlands. Tel.: +31 43 3881305; fax: +31 433670976 .

E-mail address: noud.vanherpen@hb.unimaas.nl (N.A. van Herpen).
}

type 2 diabetes and cardiovascular disease (CVD), it has been suggested that ectopic fat is a link between obesity and these diseases $[3,4]$.

Indeed, human and animal data have shown that ectopic lipid accumulation is associated with insulin resistance in muscle and liver, and with functional losses in the pancreas and the heart in animal models. The combination of insulin resistance of skeletal muscle and liver on the one hand, and pancreatic insufficiency on the other hand, are well-known factors that lead to the development of type 2 diabetes mellitus. As stated above, obesity is also an important risk factor for CVD and also here may ectopic fat deposition play a role. Indeed, data from animal models suggest a causal relationship between cardiac lipid accumulation and dilated cardiomyopathy and ultimately heart failure [5-9].

Lipid accumulation in ectopic sites can occur either by increased uptake of fatty acids (FAs), increased synthesis within the tissue involved, or reduced FA oxidation/disposal [10]. 

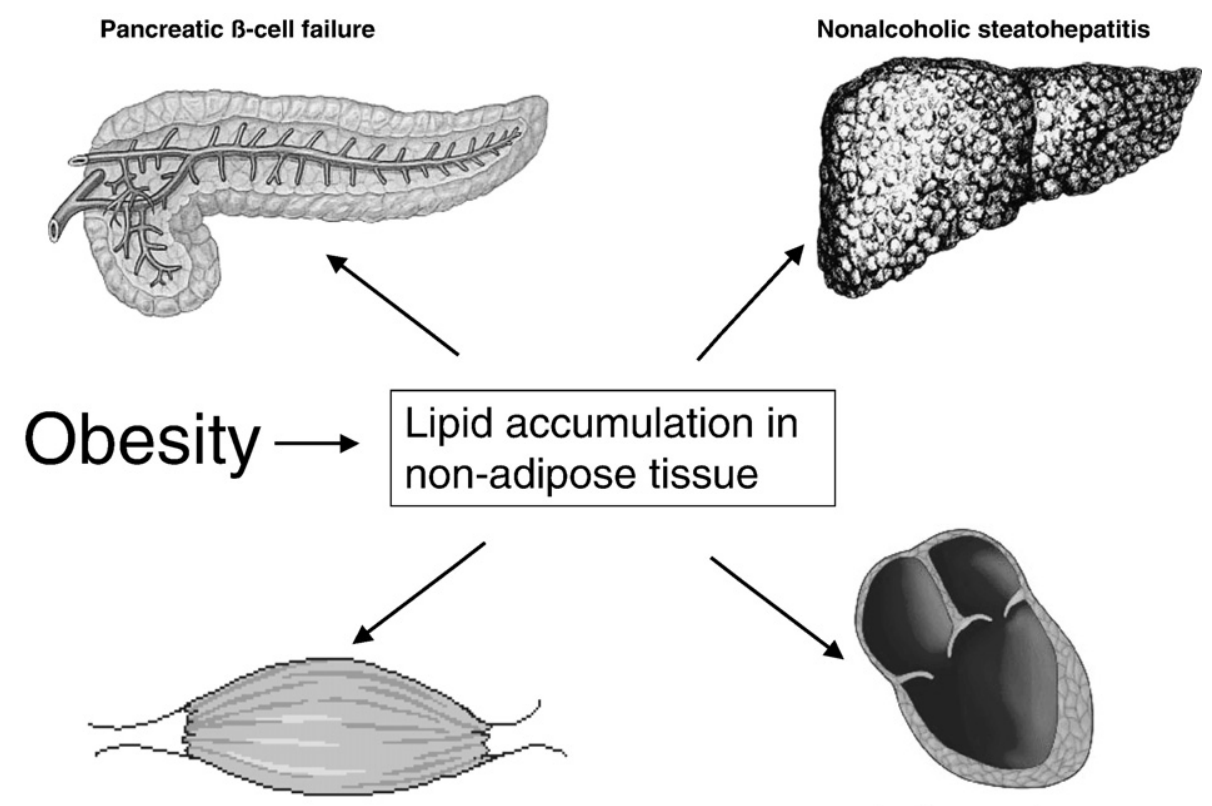

Muscle insulin resistance

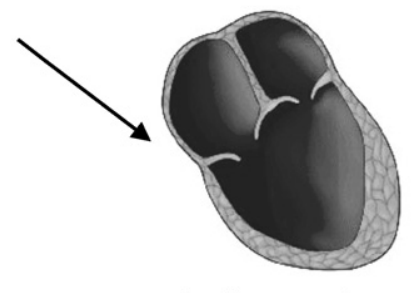

Cardiomyopathy

Fig. 1. Effects of obesity on lipid accumulation in non-adipose tissue.

However, the relative contribution of these factors to ectopic lipid accumulation varies in different physiological states and in different tissues. The purpose of this article is to review the evidence for lipotoxic mechanisms accompanying lipid storage in skeletal muscle, liver, pancreas and myocardium (see also Fig. 1).

\section{Measurement of lipid content}

Traditionally, the lipid content is quantified in a biopsy either biochemically or by electron- or light microscopy in combination with dedicated stainings. However, taking a biopsy is feasible in skeletal muscle, but lipid quantification of the human liver, the pancreas and the heart strongly depends on noninvasive methods. In these cases, very often magnetic resonance spectroscopy $\left({ }^{1} \mathrm{H}-\mathrm{MRS}\right)$ is the method of choice. In contrast to the microscopic methods, where lipids in muscle tissue can be visualized within single fibers, ${ }^{1} \mathrm{H}-\mathrm{MRS}$ measures lipid content of a larger muscle area (typically a few $\mathrm{cm} 3$ ). In a ${ }^{1} \mathrm{H}-\mathrm{MRS}$ spectrum, one can distinguish peaks originating from atoms at different chemical positions (due to a difference in shielding by electrons) and therefore one can quantify different chemical compounds if they contain mobile protons at sufficient concentrations. In muscle tissue, this is the case for e.g. water, creatine and fatty acids. Interestingly, in skeletal muscle, an additional effect plays a role (susceptibility effect). Due to slightly different magnetic properties of FA in lipid droplets inside myocytes (intramyocellular lipids, IMCL) and FA in surrounding adipose tissue (extramyocellular lipids, EMCL) and due to the parallel orientation of the adipose tissue layers in skeletal muscle relative to the magnetic field the resonance frequencies of IMCL and EMCL differ slightly, giving thus rise to two separate peaks, which allows quantifying these different lipid depots with ${ }^{1}$ H-MRS (see also Fig. 2).

\section{Skeletal muscle}

As described above, lipid droplets in healthy skeletal muscle (also known as IMCL) can be quantified by ${ }^{1} \mathrm{H}-\mathrm{MRS}$; and actually visualized by light microscopy using oil-red-O staining (see also Fig. 3) or by electron microscopy. The localization of the lipid droplets close to the mitochondria suggests that lipids inside the muscle are used as fuel for muscular activity. Based on earlier studies that have used biochemical quantification of muscular lipids there was some controversy about whether IMCL was decreased during exercise. Studies using electron microscopy and the more recent studies, using ${ }^{1} \mathrm{H}-\mathrm{MRS}$ to

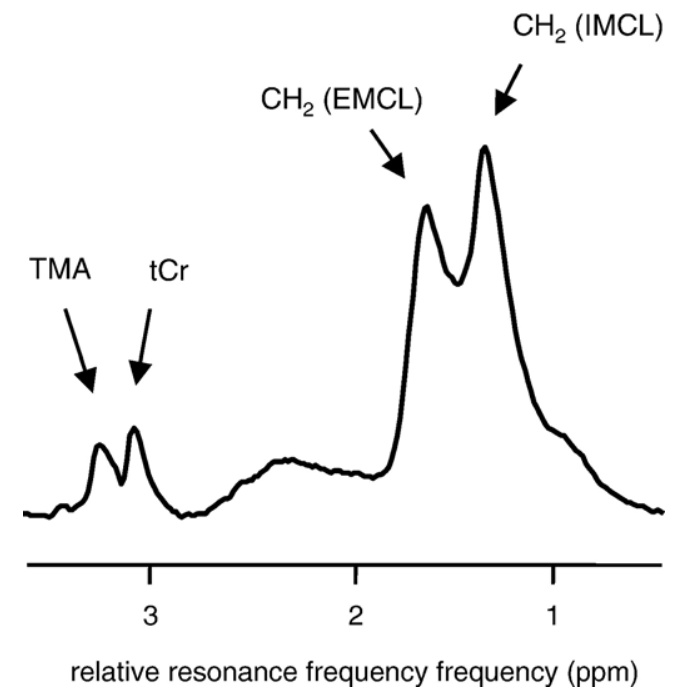

Fig. 2. Quantification of IMCL by MRS. The figure shows a spectrum from the human vastus lateralis muscle. TMA = trimehylammonium compounds, $\mathrm{tCr}=$ total creatine. The two arrows at the lower frequencies point out the peaks originating from the $\mathrm{CH}_{2}$-groups of EMCL and IMCL respectively. 
quantify IMCL, agree however on a decrease of lipids inside the muscle after exercise [11-15]. The controversy resulting from earlier studies could have been due to the large variation of biochemical lipid analysis [16]. In line with a role of IMCL as substrate during physical activity, resting IMCL content is also increased after endurance training and in particular within the (oxidative) type I fibers, which rely more on fat oxidation [11]. Considering these findings, the physiological role of IMCL as substrate source during exercise seems well established and the increase of IMCL with training is a healthy physiological response. However, it has been reported that IMCL is also increased in subjects at risk for type 2 diabetes mellitus and strongly correlates with insulin resistance in sedentary subjects $[17,18]$. From these results, it has been suggested that IMCL content may impair insulin sensitivity. This seems paradoxical in the light of the high IMCL content in trained subjects [19,20], as it is well known that endurance trained subjects are very insulin sensitive [21-23].

Interestingly, while endurance training increases resting IMCL due to an increased demand of intramyocellular substrate, a high availability of FA can also result in a high resting IMCL content. Two days to 5 weeks of a high-fat diet increases IMCL stores and this accumulation of intramuscular fat may simply be due to a positive fat balance when changing to a high-fat diet [24-28]. Physically inactive humans consuming a high-energy, high-fat diet, may have a chronically positive energy and fat balance, resulting in fat accumulation in adipose tissue and probably also in skeletal muscle. Indeed, obesity is correlated with increased IMCL [29,30]. In accordance with the above suggestion, other conditions resulting in high circulating FA availability also increase IMCL content. For example, elevation of FFA by infusion or $72 \mathrm{~h}$ of fasting [31-33]. Also, submaximal exercise, which is well known to elevate plasma FFA, results in increased IMCL content in non-active muscle [34]. Therefore, the increase of

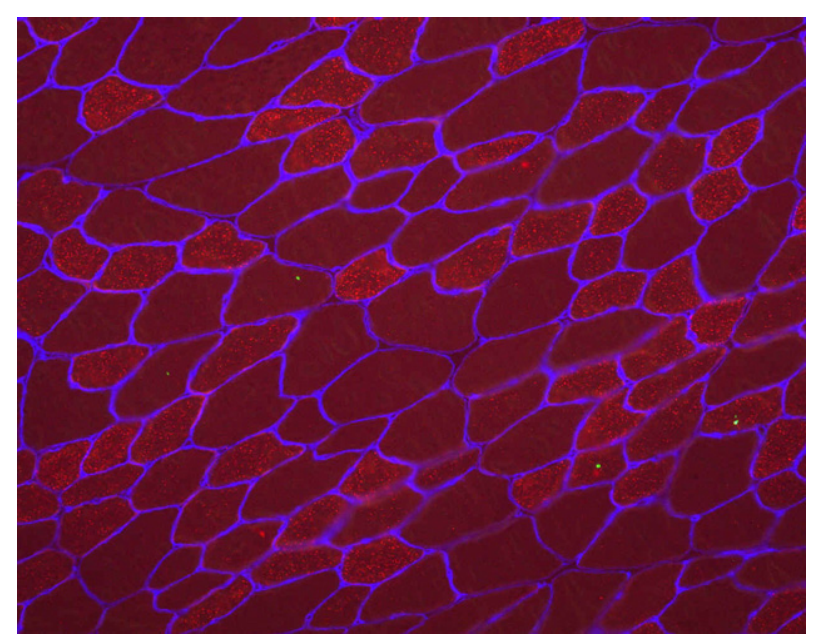

Fig. 3. Quantification of IMCL by histochemistry. The figure shows a stained section of rat tibialis anterior muscle. The red fluorescent signal originates from Oil Red O, showing IMCL; the blue fluorescent signal originates from a laminin staining, showing the cell membranes. (For interpretation of the references to colour in this figure legend, the reader is referred to the web version of this article.)
IMCL with training is a physiological adaptation that is demand-driven and paired with an increased fat oxidative capacity. Under the other conditions, fat in muscle is simply stored because the FA availability and oxidation are not in balance. These two situations can have different consequences concerning insulin resistance and strong evidence is accumulating that this is due to differential accumulation of lipid intermediates [10,35]. When fat oxidative capacity is high, concentrations of lipid intermediates such as diacylglycerol (DAG), ceramides, acyl-CoA will stay low, while situations with a high-fat availability but low fat oxidative capacity lead to increased concentrations of these intermediates [30]. In relation to insulin sensitivity, the capacity to use IMCL may be more important than IMCL levels per se. Indeed, it has been reported that correlations between acyl-CoA and insulin resistance are stronger than those between IMCL and insulin resistance [30].

For DAG it has been shown that the insulin resistance observed in human muscle when plasma FFA levels were elevated during euglycemic-hyperinsulinemic clamping was associated with increases in DAG [36]. In vitro was found that this metabolite can activate Protein Kinase C (PKC), thereby triggering a serine/threonine kinase cascade, leading to phosphorylation of serine/threonine sites on insulin receptor substrates (IRS-1 and IRS-2). This reduces the ability of the insulin receptor substrates to activate phosphatidylinositol 3kinase, which ultimately results in a reduced GLUT4 translocation to the cell membrane. In this way, increased DAG concentrations may decrease insulin-stimulated muscle glucose uptake [37-41].

\section{Liver}

The liver plays a major role in a number of vital functions. Next to playing an important role in glycogen storage, plasma protein synthesis, and drug detoxification, it is a central organ for lipid metabolism. The liver synthesizes cholesterol and TG, and produces and takes up lipoproteins. Considering this role in the trafficking of lipids, it is not surprising that hepatocytes are capable of storing lipids in the form of small droplets of TG. However, usually the hepatic lipid content is low (below 5\% of fat by wet weight) and when the liver lipid stores exceed this value, this is known as a fatty liver or liver steatosis. A wellknown cause of a fatty liver is alcohol abuse and also an unfavorable genetic predisposition increases the risk of the developing the disease [42]. Importantly, overweight and obesity are strong risk factors for non-alcoholic fatty liver disease (NAFLD) and as the prevalence of obesity is reaching pandemic proportions, a significant part of the population will be affected by liver steatosis. Figures from the US and Japan show that nowadays already up to one third of the general population may have a fatty liver $[43,44]$.

Fat accumulation in the liver is generally associated with the cluster of metabolic abnormalities related to the metabolic syndrome [45] and increased liver content is strongly correlated with insulin resistance [46-50]. It has been suggested that NAFLD, in its whole spectrum ranging from 
pure fatty liver to non-alcoholic steatohepatitis (NASH) and cryptogenice cirrhosis, which in the end may lead to hepatocellular carcinoma, is simply the hepatic manifestation of the metabolic syndrome [51,52]. Therefore, it is not surprising that a fatty liver is associated with an increased risk of all-cause death [53].

The mechanisms underlying the development of NAFLD are not completely understood but it has been shown that FA in the liver come from several different sources: dietary fat, FA released from adipose tissue, and from de novo hepatic lipogenesis. An imbalance of any of the pathways involved in FA and TG delivery, synthesis, export or oxidation could contribute to lipid accumulation in the liver.

Regarding dietary fat, many studies in mice [54] and rats $[55,56]$ have documented that a high-fat diet rapidly induces hepatic steatosis. Also in humans, it was shown that 2 weeks of high-fat diet ( $56 \%$ of energy as fat) increased lipid accumulation in the liver, while an isocaloric low fat $\operatorname{diet}(16 \%$ of total energy as fat) decreased liver fat content [57].

Interestingly, animal data suggest that saturated FA lead to more fat accumulation compared with unsaturated FA [58]. Especially, n-3 FA from fish oil appeared to be protective. As these n-3 FA are known to stimulate peroxisome proliferatorsactivated receptor- $\gamma$ (PPAR- $\gamma$ ), this effect may be due to an increased FA oxidation [59]. However, these animal studies did often use very high doses of n-3 FA and it is questionable to what extent these results can be extrapolated to the human situation [59-61]. This has only been tested in one pilot study, in which was shown that supplementation with n-3 polyunsaturated fatty acids (PUFA) improves biochemical, ultrasonographic and haemodynamic features of liver steatosis. This study supports the efficacy of n-3 PUFA as a new therapeutic approach in the treatment of NAFLD [60].

In NAFLD patients, the postprandial suppression of adipose tissue lipolysis is blunted, leading to elevated plasma FA levels, thereby providing the liver with ample substrate for reesterification of TG [62]. Therefore, adipose tissue can contribute considerably to the development of liver steatosis

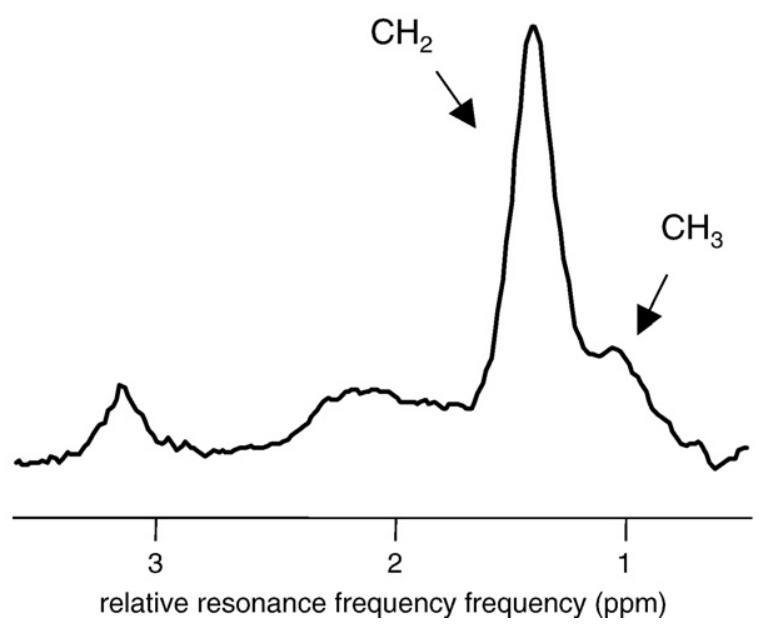

Fig. 4. Quantification of IHL by MRS. The figure shows a ${ }^{1} \mathrm{H}-\mathrm{MRS}$ spectrum from a human liver. The two arrows indicate the $\mathrm{CH}_{2}$ and the $\mathrm{CH}_{3}$ peak. by releasing FA. Additionally, adipokines released from this tissue may play an important role. For example, adiponectin (which is released from adipose tissue in quantities inversely related to adipose tissue mass) may have a protective effect, as plasma levels of adiponectin were significantly lower in subjects with NAFLD compared to body mass index (BMI) matched controls [63]. Adiponectin levels have also been found to correlate negatively with hepatic fat $[63,64]$. Further support for an important role of adiponectin comes from a mouse model, in which steatohepatitis was induced by a high-fat/alcohol diet. Adiponectin administration alleviated hepatic steatosis, and significantly attenuated hepatic inflammation and elevated levels of transaminases by increasing FA oxidation in the liver and decreasing the activities of enzymes involved in FA synthesis [65].

Next to dietary FA and FA released from adipose tissue, the liver is also capable of de novo lipogenesis. Although the de novo lipogenesis is probably not very important in healthy lean subjects [62], it has been shown in patients with NAFLD that de novo lipogenesis can contribute up to $24 \%$ of TG in the liver. This de novo lipogenesis was twice as high as the $10 \%$ reported previously in obese, hyperinsulinemic subjects [66] and is 4-5 times higher than the $5 \%$ observed in healthy populations $[67,68]$. In addition low fat/high carbohydrate diets have been shown to increase de novo lipogenesis in healthy subjects with body weights between 80 and $120 \%$ of their ideal body weight [69]. Therefore, not only a high-fat content, i.e. the above mentioned $56 \%$ of energy as fat [57], but also a high carbohydrate intake may be a concern.

It is not completely known how liver steatosis leads to insulin resistance. However, it is very likely that similarly as in skeletal muscle, not the TG per se, but the lipid intermediates are important. In vitro studies have indeed shown that increases in intracellular DAG activate PKC, which binds to and inactivates the insulin receptor kinase resulting in reduced insulin-stimulated IRS-1 and IRS-2 tyrosine phosphorylation. This in turn results in reduced insulin activation of PI 3-kinase and Akt, also known as protein kinase B (PKB). Reduced Akt/ PKB activation results in lower glycogen synthase kinase-3 phosphorylation and lower forkhead box protein O (FOXO) phosphorylation. This in turn results in lower insulin-stimulated liver glycogen synthesis and decreased suppression of hepatic gluconeogenesis, which results in an increase in GLUT2 translocation and an increase in glucose release, respectively [40]. This decreased hepatic glucose storage and higher endogenous glucose production are clearly major factors in developing impaired glucose tolerance and diabetes.

Hepatic insulin resistance is also associated with increased insulin plasma concentrations, which in turn stimulates de novo lipogenesis and therefore enhances liver steatosis further. Animal studies have clearly shown that insulin activates the membrane-bound transcription factor sterol receptor binding protein 1-c (SREBP-1c), which transcriptionally activates most genes required for lipogenesis. In mice, even in the insulin resistant state, insulin stimulates hepatic SREBP-1c transcription and increases lipogenesis [70]. In addition, overexpression of SREBP-1c in transgenic mice leads to increased lipogenesis and 
the development of hepatic steatosis [71]. On the other hand, inactivation of the SREBP-1c gene in livers of $o b / o b$ mice, a genetic model of leptin deficiency that develops obesity and hepatic steatosis, reduced the hepatic TG content by approximately $50 \%$ [72]. These data indicate that liver steatosis results in a vicious cycle by causing insulin resistance, which again favors hepatic lipid accumulation.

On the other hand, several interventional studies have demonstrated that normalization of liver fat content, which can also be measured by ${ }^{1}$ H-MRS (see also Fig. 4) [73,74], normalizes insulin resistance and disturbed glucose metabolism. In this respect, the effect of weight loss has been investigated in several studies. In these studies, it has been found for example that moderate weight loss [75] due to a low-calorie diet [76] or dietary counselling combined with increased physical activity [77] strongly reduced hepatic lipid accumulation and simultaneously improved hepatic and whole body insulin sensitivity [77,78] and splanchic glucose uptake [78].

Together, these data demonstrate that reduction of liver fat by moderate weight loss, can improve glucose metabolism in the liver. Furthermore, after treatment with pioglitazone for 16 weeks, the hepatic fat content in subjects with type 2 diabetes mellitus was decreased from $19.6 \%$ to $10.4 \%$, while the splanchic glucose uptake increased from $33.0 \%$ to $46.2 \%$. [79].

Besides hepatic insulin resistance, the inflammatory character associated with the development from liver steatosis to NASH is a concern. Although the pathogenesis of NASH has not yet been fully elucidated, it has been suggested that, next to the accumulation of FA in the liver, cytochrome P4502E1 (CYP2E1) has an important role. CYP2E1 plays a key role in the pathogenesis of alcoholic liver injury, including alcoholic steatohepatitis, because of the oxidative stress it generates $[80,81]$. Indeed, CYP2E1 concentrations increase not only in experimental animals which mimic human obesity [82], but also in morbid obese men with NAFLD or patients with NASH $[83,84]$. CYP2E1 concentrations are invariably elevated in the liver of patients with NASH [84] because FA and ketones, which are increased in diabetes, are also substrates for CYP2E1 [81]. An excess of these substrates upregulates CYP2E1. The resulting oxidative stress and liver injury are exacerbated by a diet low in carbohydrates and rich in fat, including unsaturated lipids, which promote CYP2E1 induction $[85,86]$.

Oxidative stress causes also various types of functional and structural damage and commonly increases tumour necrosis factor (TNF)- $\alpha$ production in patients with NASH [87], in addition to the already increased release of TNF- $\alpha$ by adipose tissue. Adipose tissue produces and releases a variety of cytokines (interleukin-1, TNF- $\alpha$ ), that appear to mediate the inflammatory response that accompanies obesity [88]. In addition, it is noteworthy that the expression of TNF- $\alpha$ is increased in adipose tissue of obese individuals and this expression correlates with BMI, percentage of body fat and hyperinsulinemia $[89,90]$.

Besides the release of TNF- $\alpha$ from adipose tissue and the activation via oxidative stress, obese patients with NASH also have enhanced expression of TNF- $\alpha$ mRNA in hepatic tissue, whereas obese patients without NASH have not [91]. This proinflammatory cytokine probably contributes to the inflammation and the steatosis as shown in alcoholic steatohepatitis [92]. Due to the inflammation that is associated with NASH, it is a risk factor for progressive liver disease and finally hepatocellular carcinoma.

\section{Heart}

There is increasing evidence for ectopic fat accumulation inside the heart to play a role in cardiomyopathy, and eventually heart failure, which may presently be an underestimated risk factor. Similarly as in skeletal muscle and liver, metabolic dysregulation in lipid-overloaded hearts may induce insulin resistance. Sharma et al. suggested that because failing hearts already exhibit impaired FA oxidation [93], a superimposed myocardial insulin resistance may impair glucose oxidation resulting in "energy starvation" of the heart, causing heart failure [8]. Furthermore, it has been suggested that lipid metabolites may be toxic to cardiomyocytes by inducing apoptosis $[9,94]$. Due to the limited accessibility of cardiac tissue, these cardiolipotoxic mechanisms have so far mainly been studied in rodents rather than in humans.

In one human study, the lipid content in hearts after heart failure was investigated [8]. A significantly increased intramyocardial lipid deposition was found in patients with heart failure and diabetes and/or obesity [8]. This lipid accumulation was associated with a gene expression profile similar to that in animal models of cardiac steatosis and heart failure [8]. In the Zucker diabetic fatty (ZDF) rat, a model of obesity secondary to genetic unresponsiveness to leptin, TG accumulated rapidly in the heart [9], as in other non-adipose tissues, when the animals became increasingly obese [9]. This build up of lipids was associated with a progressive increase in ceramide content and iNOS expression. By 14 weeks of age, DNA laddering was increased markedly, evidence of severe cardiac apoptosis [9]. These changes were accompanied by functional losses, as ZDF rats also developed eccentric left ventricular remodeling, increased left ventricular pressure and septal wall thickening $[5,9]$.

The extreme obesity in the ZDF rat model made it difficult to determine whether the cardiac maladaptations are related to excessive myocardial lipid accumulation or to increased expression of conventional risk factors for CVD. To address this limitation, various lean genetic mouse models of cardiacrestricted steatosis have recently been developed [5-7,94-99]. These animals displayed increased myocardial lipid content in the absence of obesity or any other traditional cardiovascular risk factors. FA accumulation in these animals can be caused by either decreased FA oxidation or increased FA uptake.

Transgenic mice with decreased cardiac FA oxidation were generated to produce cardiomyocyte-restricted deletion of PPAR- $\delta$. This down regulated constitutive expression of key FA oxidation genes and decreased basal myocardial FA oxidation. These mice had severe lipid accumulation in the heart and consequently, cardiac dysfunction, cardiac hypertrophy and congestive heart failure with reduced survival [6].

To test whether a mismatch between myocardial FA uptake and utilization may lead to the accumulation of cardiotoxic 
lipid species, a transgenic mouse line which, under a myosin heavy chain (MHC) promoter, overexpressed long-chain acylCoA synthetase (ACS) in the heart was generated. This protein plays an important role in FA transport across the membrane. The mice showed severe cardiac steatosis, systolic dysfunction and hypertrophy. The results of this study further demonstrated, that an FA uptake/utilization mismatch leads to accumulation of lipid species which are toxic to cardiac myocytes [94]. Indications of the causal relationship between cardiac steatosis and cardiac dysfunction came from results showing that reversing steatosis also restored cardiac function. The same MHC-ACS mice were made hyperleptinemic by treatment with a recombinant adenovirus containing the leptin cDNA. The heart of the hyperleptinemic MHC-ACS-transgenic mice had normalized TG contents and exhibited normal echocardiograms [7].

Another study of the reversibility of cardiac lipid storage was performed in mice treated with streptozocin, a toxin inducing diabetes by affecting pancreatic $\beta$-cells. Treatment with streptozocin led to cardiac lipid accumulation. Interestingly, overexpression of apolipoprotein B (apoB), which increases the ability of cells to secrete TG-rich lipoproteins, reversed cardiac lipid accumulation in streptozocin treated animals. Mice, treated with streptozocin, overexpressing human apoB in the heart showed a decrease of $48 \%$ in $\mathrm{TG}$ content after 12 weeks with echocardiographic indexes of heart function being normal or only marginally affected, in comparison to the wild-type mice treated with streptozocin. These findings suggest that TG accumulation in the heart is important for the development of diabetic cardiomyopathy in mice, and that apoB formation by cardiomyocytes plays an integrated role in cardiac lipid metabolism [98]. Similarly, other treatments that ameliorated cardiac lipid accumulation, by downregulation or knocking out of PPAR- $\alpha$ also rescued the heart from dilated cardiomyopathy $[96,97]$.

Taken together, there is strong evidence for lipotoxic mechanisms in rodents showing that lipid accumulation in the heart leads to heart failure. As mentioned earlier human cardiac tissue is not readily available and the study of cardiac lipid accumulation largely relies on non-invasive methods. ${ }^{1} \mathrm{H}-\mathrm{MRS}$ has been developed for quantifying lipid content in skeletal muscle and liver $[14,100,101]$. Recently ${ }^{1} \mathrm{H}-\mathrm{MRS}$ has been successfully adapted to also quantify lipid content in cardiac muscle of human subjects [102] (see also Fig. 5). The employment of this technique showed that TG was detectable in the myocardium of healthy human subjects even in those who are very lean. In overweight subjects myocardial TG content was elevated and was accompanied by increased left ventricular mass and a subtle reduction of septal wall thickening, which represents mild systolic dysfunction [102]. While it has been shown that the consumption of a single high-fat meal did not influence cardiac lipid content, despite of a 2-fold increase in serum TG, $48 \mathrm{~h}$ of fasting increased cardiac TG accumulation significantly [103]. In addition, myocardial fat was found to be higher in obese than in lean subjects and myocardial fat correlated with FFA levels, epicardial fat, and waist-to-hip ratio. Epicardial fat was positively associated with peripheral vascular a)

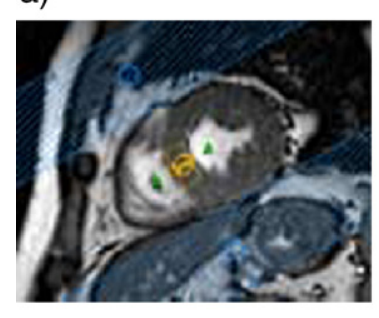

b)

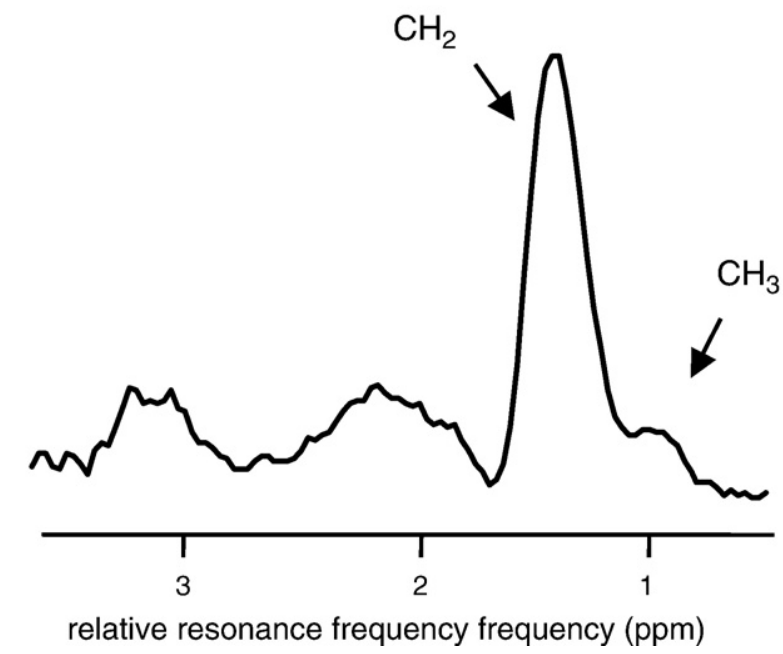

Fig. 5. ${ }^{1} \mathrm{H}-\mathrm{MRS}$ spectrum acquired from a volume of $1 \times 2 \times 3 \mathrm{~cm}$ positioned in the septum of the myocardium, as shown in the short axis view a) and four chamber view b).

resistance and negatively with the cardiac index. Together, these human data may indicate that the cardiac accumulation of TG is related to FFA exposure, generalized ectopic fat excess, and peripheral vascular resistance and that these changes precede left ventricle overload and hypertrophy [104]. Clearly, further human studies are needed to investigate this further.

\section{Pancreas}

As obesity develops, insulin secretion increases parallel to insulin resistance in order to maintain normal glucose homeostasis. Patients predisposed to diabetes, however, fail to compensate adequately for the greater insulin requirements [105]. It has also been suggested that the eventual impairment of insulin secretion in subjects with type 2 diabetes mellitus is related to ectopic fat accumulation inside the pancreas and high levels of FFA, which are both hallmarks of obesity [106,107]. Indeed, this relationship between obesity and lipid accumulation inside the pancreas, in addition to lipid accumulation inside the muscle and liver, was found in vivo in healthy MexicanAmerican girls, 14-17 years old and with a BMI ranging from $17.7 \mathrm{~kg} / \mathrm{m}^{2}$ to $46 \mathrm{~kg} / \mathrm{m} 2$ [108]. Support for the notion that chronic exposure of the $\beta$-cell to elevated FFA levels can be damaging to its function comes mainly from studies with isolated islets exposed to high concentrations of FFA for periods of 24-48 h $[109,110]$. Evidence for islet lipotoxicity in vivo comes from studies with the ZDF rat, which, as noted earlier, 
shares many of the features of obesity-related type 2 diabetes mellitus in humans. When ZDF rats $(f a / f a)$ were fed standard chow diet, the male ZDF rat developed marked hyperglycemia after 9 weeks of age [107]. This does not hold true for the fatty females or the lean littermates $(f a /+$ or $+/+)$ of the male animals. The obese ZDF females rarely exhibit hyperglycemia [111,112], although they have levels of obesity and insulin resistance comparable to males. In line with this, the male ZDF rat displayed a marked elevation of plasma FFA levels from 5 weeks of age onward, when compared to the female ZDF rat. Interestingly, just before the development of diabetes, an abrupt and massive increase in islet $\mathrm{TG}$ content appeared that coincided with severe disruption of islet morphology and $\beta$ cell function. Furthermore, energy restriction of these animals from 6 weeks of age greatly reduced their islet fat accumulation and under these circumstances islet function was largely restored and hyperglycemia did not develop. Taken together, this implicates that fat accumulation in the islet is an important contributor to $\beta$-cell failure in the ZDF rat, and probably in other rodent models of type 2 diabetes mellitus. Whether this is also true in humans is not yet clear, in part because of the scarcity of suitable pancreas specimens for histochemical analysis from individuals with increasing degrees of $\beta$-cell malfunction [113].

To show the direct relationship between fat accumulation in the pancreas and insulin secretion the reversibility of pancreatic dysfunction with normalization of TG content inside the pancreas was demonstrated in animal models. In PPAR- $\gamma-$ deficient $(P P A R-\gamma+/-)$ mice on a high-fat diet, insulin secretion was impaired and this was associated with increased islet TG content. Pioglitazone, a PPAR- $\gamma$ agonist, decreased islet TG content and simultaneously restored the impaired insulin secretion in these animals [114].

Different mechanisms by which long-term exposure to FFA can lead to $\beta$-cell dysfunction have been proposed, including effects on insulin biosynthesis, preproinsulin gene expression and the expression of uncoupling proteins (UCP).

Firstly, FFA are shown to decrease insulin biosynthesis in isolated rat islets [115]. This study also indicated that at least some FFAs exert detrimental effects on pancreatic $\beta$-cell function by impairing preproinsulin gene expression. Therefore, long-term exposure to elevated FFA levels may be a factor in the development of type 2 diabetes mellitus due to their effects on preproinsulin gene expression.

In addition long-term exposure to FFA can also modify UCP expression and thereby changing glucose-stimulated insulin secretion by uncoupling the mitochondria and decreasing ATP production. A glucose-induced change in ATP/ADP ratio plays a crucial role in the coupling of glucose metabolism to insulin secretion and any factor uncoupling ATP formation from substrate oxidation will decrease glucosestimulated insulin secretion. It has been shown that the pancreatic $\beta$-cells express the uncoupling protein UCP2 and that FAs increase its expression and partly uncouple the $\beta$-cells [116].

Furthermore, long-chain acyl-CoA (LC-CoA) may mediate the effects of FFAs. This because FFA that cannot be oxidized, may form LC-CoA and their effects on $\beta$-cell dysfunction are twofold. First, LC-CoA may activate the $\mathrm{K}_{\mathrm{ATP}}$ channel and hyperpolarize the $\beta$-cell, rendering its depolarization by glucose more difficult and decrease glucose-stimulated insulin secretion in this way [117]. Second, a constitute reservoir of LC-CoA may downregulate specific PKC isoforms and suppress their incretin action on insulin secretion [118]. Incretin action means that with matched glucose concentrations the insulin secretion is greater following ingestion of glucose than it is following infusion of glucose.

In addition to the general hazardous effects of high concentrations of FFA on $\beta$-cell function, the saturated palmitic acid seems to be specifically toxic. Among all the FAs studied in vitro on human and rodents pancreatic islets, palmitic acid rapidly induced $\beta$-cell apoptosis and reduced their proliferative capacity $[119,120]$. Increased levels of palmitic acid correlated with de novo synthesis of ceramides, known to activate the apoptotic pathway in several cell types, including the $\beta$-cells. The unsaturated oleic acid prevented apoptosis induced by palmitate, probably by mediating upregulation of the antiapoptotic protein bcl-2 [120].

In summary, fat accumulation in the pancreatic islets leads to a decreased insulin secretion and might explain why insulin resistant people cannot meet the higher demands of insulin and ultimately develop type 2 diabetes mellitus [115-120]. However, in obese nondiabetic subjects a greater proportion of pancreatic fat was associated with increased, not decreased, insulin levels. This may indicate that the deleterious effect of pancreatic fat accumulation might require a long time before manifesting in impaired $\beta$-cell function. Indeed, it has been estimated that pancreatic $\beta$-cell damage is present for more than a decade before diabetes is diagnosed [121].

\section{Conclusion}

The Health Survey for England showed that in 2-10 year old children, $16 \%$ of boys and $12 \%$ of girls were obese (BMI $>=95$ th percentile), and that in 11-15 year olds a staggering $24 \%$ of boys and $26 \%$ of girls were obese in 2004 [122]. Unfortunately, the alarming consequences of overweight and obesity are likely to increase as well as this new generation of overweight children with a longer duration of excess body weight, than any of their overweight predecessors, reaches adulthood.

It is well known that overweight and obesity are strong risk factors for cardiovascular disease and type 2 diabetes mellitus, which put a heavy load on the health care systems. As reviewed here, ectopic lipid accumulation may be a link between an increased body fat mass and these diseases. To summarize, there is strong evidence from human studies that hepatic and intramuscular lipid accumulation can cause insulin resistance in these tissues. Rodent data further suggest that pancreatic insufficiency may also occur due to excessive exposure to lipids. The combination of insulin resistance of skeletal muscle and liver on the one hand, and pancreatic insufficiency on the other hand, are the factors well known to lead to the development of type 2 diabetes mellitus. As stated above, obesity is also an important risk factor for CVD and also here, ectopic fat deposition may play an important role. Indeed, 
data from animal models suggest a causal relationship between cardiac lipid accumulation and dilated cardiomyopathy and ultimately heart failure.

Taken together, we conclude that evidence for a hazardous role of lipid accumulation in non-adipose tissue (lipotoxicity) is strong. However, while quite a lot of human data is available from skeletal muscle and liver, future research should focus on lipid accumulation in the human pancreas and the heart. Newly available non-invasive methods, i.e. ${ }^{1} \mathrm{H}-\mathrm{MRS}$, make it possible to conduct interventions to investigate the causes, the timecourse and the consequences of lipid accumulation in all of these tissues and to investigate the effectiveness of possible treatments.

\section{References}

[1] Unger RH, Orci L. Diseases of liporegulation: new perspective on obesity and related disorders. Faseb J 2001;15:312-21.

[2] Schaffer JE. Lipotoxicity: when tissues overeat. Curr Opin Lipidol 2003;14:281-7.

[3] Roger VL, Weston SA, Redfield MM, Hellermann-Homan JP, Killian J, Yawn BP, et al. Trends in heart failure incidence and survival in a community-based population. Jama 2004;292:344-50.

[4] Wilson PW, D'Agostino RB, Sullivan L, Parise H, Kannel WB. Overweight and obesity as determinants of cardiovascular risk: the Framingham experience. Arch Intern Med 2002;162:1867-72.

[5] Bjorkegren J, Veniant M, Kim SK, Withycombe SK, Wood PA, Hellerstein MK, et al. Lipoprotein secretion and triglyceride stores in the heart. J Biol Chem 2001;276:38511-7.

[6] Cheng L, Ding G, Qin Q, Huang Y, Lewis W, He N, et al. Cardiomyocyterestricted peroxisome proliferator-activated receptor-delta deletion perturbs myocardial fatty acid oxidation and leads to cardiomyopathy. Nat Med 2004;10:1245-50.

[7] Lee Y, Naseem RH, Duplomb L, Park BH, Garry DJ, Richardson JA, et al. Hyperleptinemia prevents lipotoxic cardiomyopathy in acyl CoA synthase transgenic mice. Proc Natl Acad Sci U S A 2004;101:13624-9.

[8] Sharma S, Adrogue JV, Golfman L, Uray I, Lemm J, Youker K, et al. Intramyocardial lipid accumulation in the failing human heart resembles the lipotoxic rat heart. Faseb J 2004;18:1692-700.

[9] Zhou YT, Grayburn P, Karim A, Shimabukuro M, Higa M, Baetens D, et al. Lipotoxic heart disease in obese rats: implications for human obesity. Proc Natl Acad Sci U S A 2000;97:1784-9.

[10] Shulman GI. Cellular mechanisms of insulin resistance. J Clin Invest 2000;106:171-6.

[11] Schrauwen-Hinderling VB, Schrauwen P, Hesselink MK, van Engelshoven JM, Nicolay K, Saris WH, et al. The increase in intramyocellular lipid content is a very early response to training. J Clin Endocrinol Metab 2003;88:1610-6.

[12] Rico-Sanz J, Moosavi M, Thomas EL, McCarthy J, Coutts GA, Saeed N, et al. In vivo evaluation of the effects of continuous exercise on skeletal muscle triglycerides in trained humans. Lipids 2000;35:1313-8.

[13] Krssak M, Petersen KF, Bergeron R, Price T, Laurent D, Rothman DL, et al. Intramuscular glycogen and intramyocellular lipid utilization during prolonged exercise and recovery in man: $\mathrm{a}^{13} \mathrm{C}$ and ${ }^{1} \mathrm{H}$ nuclear magnetic resonance spectroscopy study. J Clin Endocrinol Metab 2000;85:748-54.

[14] Boesch C, Slotboom J, Hoppeler H, Kreis R. In vivo determination of intra-myocellular lipids in human muscle by means of localized ${ }^{1} \mathrm{H}-\mathrm{MR}$ spectroscopy. Magn Reson Med 1997;37:484-93.

[15] Brechtel K, Niess AM, Machann J, Rett K, Schick F, Claussen CD, et al. Utilisation of intramyocellular lipids (IMCLs) during exercise as assessed by proton magnetic resonance spectroscopy $\left({ }^{1} \mathrm{H}-\mathrm{MRS}\right)$. Horm Metab Res 2001;33:63-6.
[16] Wendling PS, Peters SJ, Heigenhauser GJ, Spriet LL. Variability of triacylglycerol content in human skeletal muscle biopsy samples. J Appl Physiol 1996;81:1150-5.

[17] Jacob S, Machann J, Rett K, Brechtel K, Volk A, Renn W, et al. Association of increased intramyocellular lipid content with insulin resistance in lean nondiabetic offspring of type 2 diabetic subjects. Diabetes 1999;48:1113-9.

[18] Krssak M, Falk Petersen K, Dresner A, Dresner A, DiPietro L, Vogel SM, et al. Intramyocellular lipid concentrations are correlated with insulin sensitivity in humans: a ${ }^{1} \mathrm{H}$ NMR spectroscopy study. Diabetologia 1999;42:113-6.

[19] Goodpaster BH, He J, Watkins S, Kelley DE. Skeletal muscle lipid content and insulin resistance: evidence for a paradox in endurancetrained athletes. J Clin Endocrinol Metab 2001;86:5755-61.

[20] Thamer C, Machann J, Bachmann O, Haap M, Dahl D, Wietek B, et al. Intramyocellular lipids: anthropometric determinants and relationships with maximal aerobic capacity and insulin sensitivity. J Clin Endocrinol Metab 2003;88:1785-91.

[21] Horton ES. Exercise and physical training: effects on insulin sensitivity and glucose metabolism. Diabetes Metab Rev 1986;2:1-17.

[22] Mikines KJ, Sonne B, Farrell PA, Tronier B, Galbo H. Effect of physical exercise on sensitivity and responsiveness to insulin in humans. Am J Physiol 1988;254:E248-59.

[23] Rosenthal M, Haskell WL, Solomon R, Widstrom A, Reaven GM. Demonstration of a relationship between level of physical training and insulin-stimulated glucose utilization in normal humans. Diabetes 1983;32:408-11.

[24] Hill JO, Peters JC, Reed GW, Schlundt DG, Sharp T, Greene HL. Nutrient balance in humans: effects of diet composition. Am J Clin Nutr 1991;54:10-7.

[25] Vogt M, Puntschart A, Howald H, Mueller B, Mannhart C, GfellerTuescher L, et al. Effects of dietary fat on muscle substrates, metabolism, and performance in athletes. Med Sci Sports Exerc 2003;35:952-60.

[26] Helge JW, Watt PW, Richter EA, Rennie MJ, Kiens B. Fat utilization during exercise: adaptation to a fat-rich diet increases utilization of plasma fatty acids and very low density lipoprotein-triacylglycerol in humans. J Physiol 2001;537:1009-20.

[27] Johnson NA, Stannard SR, Mehalski K, Trenell MI, Sachinwalla T, Thompson $\mathrm{CH}$, et al. Intramyocellular triacylglycerol in prolonged cycling with high- and low-carbohydrate availability. J Appl Physiol 2003;94:1365-72.

[28] Zderic TW, Davidson CJ, Schenk S, Byerley LO, Coyle EF. High-fat diet elevates resting intramuscular triglyceride concentration and whole body lipolysis during exercise. Am J Physiol Endocrinol Metab 2004;286: E217-25.

[29] Forouhi NG, Jenkinson G, Thomas EL, Mullick S, Mierisova S, Bhonsle $\mathrm{U}$, et al. Relation of triglyceride stores in skeletal muscle cells to central obesity and insulin sensitivity in European and South Asian men. Diabetologia 1999;42:932-5.

[30] Hulver MW, Berggren JR, Cortright RN, Dudek RW, Thompson RP, Pories WJ, et al. Skeletal muscle lipid metabolism with obesity. Am J Physiol Endocrinol Metab 2003;284:E741-7.

[31] Bachmann OP, Dahl DB, Brechtel K, Machann J, Haap M, Maier T, et al. Effects of intravenous and dietary lipid challenge on intramyocellular lipid content and the relation with insulin sensitivity in humans. Diabetes 2001;50:2579-84.

[32] Boden G, Lebed B, Schatz M, Homko C, Lemieux S. Effects of acute changes of plasma free fatty acids on intramyocellular fat content and insulin resistance in healthy subjects. Diabetes 2001;50:1612-7.

[33] Stannard SR, Thompson MW, Fairbairn K, Huard B, Sachinwalla T, Thompson CH. Fasting for $72 \mathrm{~h}$ increases intramyocellular lipid content in nondiabetic, physically fit men. Am J Physiol Endocrinol Metab 2002;283:E1185-91.

[34] Schrauwen-Hinderling VB, van Loon LJ, Koopman R, Nicolay K, Saris WH, Kooi ME. Intramyocellular lipid content is increased after exercise in nonexercising human skeletal muscle. J Appl Physiol 2003;95: $2328-32$. 
[35] Kelley DE, Mandarino LJ. Fuel selection in human skeletal muscle in insulin resistance: a reexamination. Diabetes 2000;49:677-83.

[36] Itani SI, Ruderman NB, Schmieder F, Boden G. Lipid-induced insulin resistance in human muscle is associated with changes in diacylglycerol, protein kinase C, and IkappaB-alpha. Diabetes 2002;51:2005-11.

[37] Dresner A, Laurent D, Marcucci M, Griffin ME, Dufour S, Cline GW, et al. Effects of free fatty acids on glucose transport and IRS-1-associated phosphatidylinositol 3-kinase activity. J Clin Invest 1999;103:253-9.

[38] Griffin ME, Marcucci MJ, Cline GW, Bell K, Barucci N, Lee D, et al. Free fatty acid-induced insulin resistance is associated with activation of protein kinase $\mathrm{C}$ theta and alterations in the insulin signaling cascade. Diabetes 1999;48:1270-4.

[39] Morino K, Petersen KF, Dufour S, Befroy D, Frattini J, Shatzkes N, et al. Reduced mitochondrial density and increased IRS-1 serine phosphorylation in muscle of insulin-resistant offspring of type 2 diabetic parents. J Clin Invest 2005;115:3587-93.

[40] Savage DB, Petersen KF, Shulman GI. Disordered lipid metabolism and the pathogenesis of insulin resistance. Physiol Rev 2007;87:507-20.

[41] Yu C, Chen Y, Cline GW, Zhang D, Zong H, Wang Y, et al. Mechanism by which fatty acids inhibit insulin activation of insulin receptor substrate-1 (IRS-1)-associated phosphatidylinositol 3-kinase activity in muscle. J Biol Chem 2002;277:50230-6.

[42] Reuben A. Alcohol and the liver. Current Opinion in Gastroenterology 2007;23:283-91.

[43] Browning JD, Szczepaniak LS, Dobbins R, Nuremberg P, Horton JD, Cohen JC, et al. Prevalence of hepatic steatosis in an urban population in the United States: impact of ethnicity. Hepatology 2004;40:1387-95.

[44] Jimba S, Nakagami T, Takahashi M, Wakamatsu T, Hirota Y, Iwamoto Y, et al. Prevalence of non-alcoholic fatty liver disease and its association with impaired glucose metabolism in Japanese adults. Diabet Med 2005;22:1141-5

[45] Unger RH. Lipotoxic diseases. Annu Rev Med 2002;53:319-36.

[46] Kotronen A, Juurinen L, Hakkarainen A, Westerbacka J, Corner A, Bergholm R, et al. Liver fat is increased in type 2 diabetic patients and underestimated by serum alt compared to equally obese non-diabetic subjects. Diabetes Care 2007;31(1):165-9.

[47] Kotronen A, Vehkavaara S, Seppala-Lindroos A, Bergholm R, YkiJarvinen, H. Effect of liver fat on insulin clearance. Am J Physiol Endocrinol Metab 2007;293(6):E1709-15.

[48] Kotronen A, Westerbacka J, Bergholm R, Pietilainen KH, Yki-Jarvinen H. Liver fat in the metabolic syndrome. J Clin Endocrinol Metab 2007;92:3490-7.

[49] Yki-Jarvinen H. Fat in the liver and insulin resistance. Annals of Medicine 2005;37:347-56.

[50] Yki-Jarvinen H, Westerbacka J. The fatty liver and insulin resistance. Current Molecular Medicine 2005;5:287-95.

[51] Marchesini G, Bugianesi E, Forlani G, Cerrelli F, Lenzi M, Manini R, et al. Nonalcoholic fatty liver, steatohepatitis, and the metabolic syndrome Hepatology 2003;37:917-23.

[52] Marchesini G, Marzocchi R, Agostini F, Bugianesi E. Nonalcoholic fatty liver disease and the metabolic syndrome. Curr Opin Lipidol 2005; $16: 421-7$.

[53] Adams LA, Angulo P. Recent concepts in non-alcoholic fatty liver disease. Diabet Med 2005;22:1129-33.

[54] McCuskey RS, Ito Y, Robertson GR, McCuskey MK, Perry M, Farrell GC. Hepatic microvascular dysfunction during evolution of dietary steatohepatitis in mice. Hepatology 2004;40:386-93.

[55] Lieber CS, Leo MA, Mak KM, Xu Y, Cao Q, Ren C, et al. Model of nonalcoholic steatohepatitis. Am J Clin Nutr 2004;79:502-9.

[56] Samuel VT, Liu ZX, Qu X, Elder BD, Bilz S, Befroy D, et al. Mechanism of hepatic insulin resistance in non-alcoholic fatty liver disease. J Biol Chem 2004;279:32345-53.

[57] Westerbacka J, Lammi K, Hakkinen AM, Rissanen A, Salminen I, Aro A, et al. Dietary fat content modifies liver fat in overweight nondiabetic subjects. J Clin Endocrinol Metab 2005;90:2804-9.

[58] Videla LA, Rodrigo R, Araya J, Poniachik J. Oxidative stress and depletion of hepatic long-chain polyunsaturated fatty acids may contribute to nonalcoholic fatty liver disease. Free Radic Biol Med 2004;37:1499-507.
[59] Delarue J, LeFoll C, Corporeau C, Lucas D. N-3 long chain polyunsaturated fatty acids: a nutritional tool to prevent insulin resistance associated to type 2 diabetes and obesity? Reprod Nutr Dev 2004;44:289-99.

[60] Capanni M, Calella F, Biagini MR, Genise S, Raimondi L, Bedogni G, et al. Prolonged n-3 polyunsaturated fatty acid supplementation ameliorates hepatic steatosis in patients with non-alcoholic fatty liver disease: a pilot study. Aliment Pharmacol Ther 2006;23:1143-51.

[61] Demirel G, Wachira AM, Sinclair LA, Wilkinson RG, Wood JD, Enser M. Effects of dietary n-3 polyunsaturated fatty acids, breed and dietary vitamin $\mathrm{E}$ on the fatty acids of lamb muscle, liver and adipose tissue. Br J Nutr 2004;91:551-65

[62] Donnelly KL, Smith CI, Schwarzenberg SJ, Jessurun J, Boldt MD, Parks EJ. Sources of fatty acids stored in liver and secreted via lipoproteins in patients with nonalcoholic fatty liver disease. J Clin Invest 2005;115:1343-51.

[63] Hui JM, Hodge A, Farrell GC, Kench JG, Kriketos A, George J. Beyond insulin resistance in NASH: TNF-alpha or adiponectin? Hepatology 2004;40:46-54.

[64] Bugianesi E, Pagotto U, Manini R, Vanni E, Gastaldelli A, de Iasio R, et al. Plasma adiponectin in nonalcoholic fatty liver is related to hepatic insulin resistance and hepatic fat content, not to liver disease severity. J Clin Endocrinol Metab 2005;90:3498-504.

[65] Xu A, Wang Y, Keshaw H, Xu LY, Lam KS, Cooper GJ. The fat-derived hormone adiponectin alleviates alcoholic and nonalcoholic fatty liver diseases in mice. J Clin Invest 2003;112:91-100.

[66] Schwarz JM, Linfoot P, Dare D, Aghajanian K. Hepatic de novo lipogenesis in normoinsulinemic and hyperinsulinemic subjects consuming high-fat, low-carbohydrate and low-fat, high-carbohydrate isoenergetic diets. Am J Clin Nutr 2003;77:43-50.

[67] Hudgins LC, Hellerstein MK, Seidman CE, Neese RA, Tremaroli JD, Hirsch J. Relationship between carbohydrate-induced hypertriglyceridemia and fatty acid synthesis in lean and obese subjects. J Lipid Res 2000;41:595-604.

[68] Parks EJ. Dietary carbohydrate's effects on lipogenesis and the relationship of lipogenesis to blood insulin and glucose concentrations. Br J Nutr 2002;87:S247-53 Supp1 2.

[69] Hudgins LC, Hellerstein M, Seidman C, Neese R, Diakun J, Hirsch J. Human fatty acid synthesis is stimulated by a eucaloric low fat, high carbohydrate diet. J Clin Invest 1996;97:2081-91.

[70] Shimomura I, Bashmakov Y, Horton JD. Increased levels of nuclear SREBP-1c associated with fatty livers in two mouse models of diabetes mellitus. J Biol Chem 1999;274:30028-32.

[71] Shimano H, Horton JD, Shimomura I, Hammer RE, Brown MS, Goldstein JL. Isoform 1c of sterol regulatory element binding protein is less active than isoform 1a in livers of transgenic mice and in cultured cells. J Clin Invest 1997;99:846-54

[72] Yahagi N, Shimano H, Hasty AH, Matsuzaka T, Ide T, Yoshikawa T, et al. Absence of sterol regulatory element-binding protein-1 (SREBP-1) ameliorates fatty livers but not obesity or insulin resistance in $\operatorname{Lep}(o b)$ / Lep $(o b)$ mice. J Biol Chem 2002;277:19353-7.

[73] Machann J, Thamer C, Schnoedt B, Stefan N, Haring HU, Claussen CD, et al. Hepatic lipid accumulation in healthy subjects: a comparative study using spectral fat-selective MRI and volume-localized ${ }^{1} \mathrm{H}-\mathrm{MR}$ spectroscopy. Magn Reson Med 2006;55:913-7.

[74] Szczepaniak LS, Nurenberg P, Leonard D, Browning JD, Reingold JS, Grundy S, et al. Magnetic resonance spectroscopy to measure hepatic triglyceride content: prevalence of hepatic steatosis in the general population. Am J Physiol Endocrinol Metab 2005;288:E462-8.

[75] Tiikkainen M, Bergholm R, Vehkavaara S, Rissanen A, Hakkinen AM, Tamminen M, et al. Effects of identical weight loss on body composition and features of insulin resistance in obese women with high and low liver fat content. Diabetes 2003;52:701-7.

[76] Petersen KF, Dufour S, Befroy D, Lehrke M, Hendler RE, Shulman GI, et al. Reversal of nonalcoholic hepatic steatosis, hepatic insulin resistance, and hyperglycemia by moderate weight reduction in patients with type 2 diabetes. Diabetes 2005;54:603-8.

[77] Schafer S, Kantartzis K, Machann J, Venter C, Niess A, Schick F, et al. Lifestyle intervention in individuals with normal versus impaired glucose tolerance. Eur J Clin Invest 2007;37:535-43. 
[78] Sato F, Tamura Y, Watada H, Kumashiro N, Igarashi Y, Uchino H, et al. Effects of diet-induced moderate weight reduction on intrahepatic and intramyocellular triglycerides and glucose metabolism in obese subjects. J Clin Endocrinol Metab 2007;92(8):3326-9.

[79] Bajaj M, Suraamornkul S, Pratipanawatr T, Hardies LJ, Pratipanawatr W, Glass L, et al. Pioglitazone reduces hepatic fat content and augments splanchnic glucose uptake in patients with type 2 diabetes. Diabetes 2003;52:1364-70.

[80] Lieber CS. Medical and nutritional complications of alcoholism: mechanisms and management. New York: Plenum Press; 1992.

[81] Lieber CS. Cytochrome P-4502E1: its physiological and pathological role. Physiol Rev 1997;77:517-44.

[82] Raucy JL, Lasker JM, Kraner JC, Salazar DE, Lieber CS, Corcoran GB. Induction of cytochrome P450IIE1 in the obese overfed rat. Mol Pharmacol 1991;39:275-80.

[83] Emery MG, Fisher JM, Chien JY, Kharasch ED, Dellinger EP, Kowdley $\mathrm{KV}$, et al. CYP2E1 activity before and after weight loss in morbidly obese subjects with nonalcoholic fatty liver disease. Hepatology 2003;38: 428-35.

[84] Weltman MD, Farrell GC, Hall P, Ingelman-Sundberg M, Liddle C. Hepatic cytochrome P450 2E1 is increased in patients with nonalcoholic steatohepatitis. Hepatology 1998;27:128-33.

[85] Teschke R, Moreno F, Petrides AS. Hepatic microsomal ethanol oxidizing system (MEOS): respective roles of ethanol and carbohydrates for the enhanced activity after chronic alcohol consumption. Biochem Pharmacol 1981;30:1745-51.

[86] Yoo JS, Ning SM, Pantuck CB, Pantuck EJ, Yang CS. Regulation of hepatic microsomal cytochrome P450IIE1 level by dietary lipids and carbohydrates in rats. J Nutr 1991;121:959-65.

[87] Pessayre D, Mansouri A, Fromenty B. Nonalcoholic steatosis and steatohepatitis. V. Mitochondrial dysfunction in steatohepatitis. Am J Physiol Gastrointest Liver Physiol 2002;282:G193-9.

[88] Aggarwal BB, Natarajan K. Tumor necrosis factors: developments during the last decade. Eur Cytokine Netw 1996;7:93-124.

[89] Hotamisligil GS, Arner P, Caro JF, Atkinson RL, Spiegelman BM. Increased adipose tissue expression of tumor necrosis factor-alpha in human obesity and insulin resistance. J Clin Invest 1995;95:2409-15.

[90] Ronti T, Lupattelli G, Mannarino E. The endocrine function of adipose tissue: an update. Clin Endocrinol (Oxf) 2006;64:355-65.

[91] Crespo J, Cayon A, Fernandez-Gil P, Hernandez-Guerra M, Mayorga M, Dominguez-Diez A, et al. Gene expression of tumor necrosis factor alpha and TNF-receptors, p55 and p75, in nonalcoholic steatohepatitis patients. Hepatology 2001;34:1158-63.

[92] Yin M, Wheeler MD, Kono H, Bradford BU, Gallucci RM, Luster MI, et al. Essential role of tumor necrosis factor alpha in alcohol-induced liver injury in mice. Gastroenterology 1999;117:942-52.

[93] Sack MN, Rader TA, Park S, Bastin J, McCune SA, Kelly DP. Fatty acid oxidation enzyme gene expression is downregulated in the failing heart. Circulation 1996;94:2837-42.

[94] Chiu HC, Kovacs A, Ford DA, Hsu FF, Garcia R, Herrero P, et al. A novel mouse model of lipotoxic cardiomyopathy. J Clin Invest 2001; 107:813-22.

[95] Chiu HC, Kovacs A, Blanton RM, Han X, Courtois M, Weinheimer CJ, et al. Transgenic expression of fatty acid transport protein 1 in the heart causes lipotoxic cardiomyopathy. Circ Res 2005;96:225-33.

[96] Dewald O, Sharma S, Adrogue J, Salazar R, Duerr GD, Crapo JD, et al. Downregulation of peroxisome proliferator-activated receptor-alpha gene expression in a mouse model of ischemic cardiomyopathy is dependent on reactive oxygen species and prevents lipotoxicity. Circulation 2005;112:407-15.

[97] Finck BN, Han X, Courtois M, Aimond F, Nerbonne JM, Kovacs A, et al. A critical role for PPARalpha-mediated lipotoxicity in the pathogenesis of diabetic cardiomyopathy: modulation by dietary fat content. Proc Natl Acad Sci U S A 2003;100:1226-31.

[98] Nielsen LB, Bartels ED, Bollano E. Overexpression of apolipoprotein B in the heart impedes cardiac triglyceride accumulation and development of cardiac dysfunction in diabetic mice. J Biol Chem 2002;277: 27014-20.
[99] Yagyu H, Chen G, Yokoyama M, Hirata K, Augustus A, Kako Y, et al. Lipoprotein lipase (LpL) on the surface of cardiomyocytes increases lipid uptake and produces a cardiomyopathy. J Clin Invest 2003;111:419-26.

[100] Schick F, Eismann B, Jung WI, Bongers H, Bunse M, Lutz O. Comparison of localized proton NMR signals of skeletal muscle and fat tissue in vivo: two lipid compartments in muscle tissue. Magn Reson Med 1993;29:158-67.

[101] Thomsen C, Becker U, Winkler K, Christoffersen P, Jensen M, Henriksen O. Quantification of liver fat using magnetic resonance spectroscopy. Magn Reson Imaging 1994;12:487-95.

[102] Szczepaniak LS, Dobbins RL, Metzger GJ, Sartoni-D’Ambrosia G, Arbique D, Vongpatanasin W, et al. Myocardial triglycerides and systolic function in humans: in vivo evaluation by localized proton spectroscopy and cardiac imaging. Magn Reson Med 2003;49:417-23.

[103] Reingold JS, McGavock JM, Kaka S, Tillery T, Victor RG, Szczepaniak LS, et al. Determination of triglyceride in the human myocardium by magnetic resonance spectroscopy: reproducibility and sensitivity of the method. Am J Physiol Endocrinol Metab 2005;289:E935-9.

[104] Kankaanpaa M, Lehto HR, Parkka JP, Komu M, Viljanen A, Ferrannini E, et al. Myocardial triglyceride content and epicardial fat mass in human obesity: relationship to left ventricular function and serum free fatty acid levels. J Clin Endocrinol Metab 2006;91:4689-95.

[105] Poitout V. Beta-cell lipotoxicity: burning fat into heat? Endocrinology 2004; 145:3563-5.

[106] Carpentier A, Mittelman SD, Bergman RN, Giacca A, Lewis GF Prolonged elevation of plasma free fatty acids impairs pancreatic beta-cell function in obese nondiabetic humans but not in individuals with type 2 diabetes. Diabetes 2000;49:399-408.

[107] Lee Y, Hirose H, Ohneda M, Johnson JH, McGarry JD, Unger RH. Betacell lipotoxicity in the pathogenesis of non-insulin-dependent diabetes mellitus of obese rats: impairment in adipocyte-beta-cell relationships. Proc Natl Acad Sci U S A 1994;91:10878-82.

[108] Kovanlikaya A, Mittelman SD, Ward A, Geffner ME, Dorey F, Gilsanz V. Obesity and fat quantification in lean tissues using three-point Dixon MR imaging. Pediatr Radiol 2005;35:601-7.

[109] Bollheimer LC, Skelly RH, Chester MW, McGarry JD, Rhodes CJ. Chronic exposure to free fatty acid reduces pancreatic beta cell insulin content by increasing basal insulin secretion that is not compensated for by a corresponding increase in proinsulin biosynthesis translation. J Clin Invest 1998;101:1094-101.

[110] Zhou YP, Grill V. Long term exposure to fatty acids and ketones inhibits B-cell functions in human pancreatic islets of Langerhans. J Clin Endocrinol Metab 1995;80:1584-90.

[111] Clark JB, Palmer CJ, Shaw WN. The diabetic Zucker fatty rat. Proc Soc Exp Biol Med 1983;173:68-75.

[112] Peterson RG, Shaw WN, Neel MA, Little LA, Eichberg J. Zucker diabetic fatty rat as a model for non-insulin-dependent diabetes mellitus. ILAR news 1990;32:16-9.

[113] McGarry JD. Banting lecture 2001: dysregulation of fatty acid metabolism in the etiology of type 2 diabetes. Diabetes 2002;51:7-18.

[114] Matsui J, Terauchi Y, Kubota N, Takamoto I, Eto K, Yamashita T, et al. Pioglitazone reduces islet triglyceride content and restores impaired glucose-stimulated insulin secretion in heterozygous peroxisome proliferator-activated receptor-gamma-deficient mice on a high-fat diet. Diabetes 2004;53:2844-54.

[115] Ritz-Laser B, Meda P, Constant I, Klages N, Charollais A, Morales A, et al. Glucose-induced preproinsulin gene expression is inhibited by the free fatty acid palmitate. Endocrinology 1999;140:4005-14.

[116] Lameloise N, Muzzin P, Prentki M, Assimacopoulos-Jeannet F. Uncoupling protein 2: a possible link between fatty acid excess and impaired glucose-induced insulin secretion? Diabetes 2001;50:803-9.

[117] Branstrom R, Leibiger IB, Leibiger B, Corkey BE, Berggren PO, Larsson O. Long chain coenzyme A esters activate the pore-forming subunit (Kir6. 2) of the ATP-regulated potassium channel. J Biol Chem 1998;273:31395-400.

[118] Liang Y, Buettger C, Berner DK, Matschinsky FM. Chronic effect of fatty acids on insulin release is not through the alteration of glucose metabolism in a pancreatic beta-cell line (beta HC9). Diabetologia 1997;40:1018-27. 
[119] El-Assaad W, Buteau J, Peyot ML, Nolan C, Roduit R, Hardy S, et al. Saturated fatty acids synergize with elevated glucose to cause pancreatic beta-cell death. Endocrinology 2003;144:4154-63.

[120] Maedler K, Oberholzer J, Bucher P, Spinas GA, Donath MY Monounsaturated fatty acids prevent the deleterious effects of palmitate and high glucose on human pancreatic beta-cell turnover and function. Diabetes 2003;52:726-33.
[121] Oakes ND, Bell KS, Furler SM, Camilleri S, Saha AK, Ruderman NB, et al. Diet-induced muscle insulin resistance in rats is ameliorated by acute dietary lipid withdrawal or a single bout of exercise: parallel relationship between insulin stimulation of glucose uptake and suppression of long-chain fatty acyl-CoA. Diabetes 1997;46:2022-8.

[122] Updating of trend tables to include childhood obesity data. Health Survey for England; 2004. www.ic.nhs.uk/pubs/hsechildobesityupdate. 